УДК 930.253:94(477-25)

\title{
Кучерук Олександр,
}

Завідувач відділу «Музей Української революиії 1917-1921 рр.» Начіонального музею історії Украӥни

\section{БУДИНОК ЦЕНТРАЛЬНОЇ РАДИ У КИЄВІ: ТРАНСФОРМАЦІЇ ОБРАЗУ}

У статті розглянуто історію будівництва та функиіонування будівлі у місті Києві за адресою вул. Володимирська 57, яка під час Української революиії використовувалась як приміщення Української Центральної Ради. Проаналізовано будівництво та концепт, за яким зводився иеей будинок, представлено опис внутрішнього та зовнішнього оздоблення. Докладно розкрито процес переходу будівлі до статусу дому засідань Центральної Ради. Досліджено подальша доля Будинку Центральної Ради, розкрита функціональна трансформація, щзо відбувалася з ним у різні періоди його існування.

Ключові слова: будинок Центральної Ради, будівництво, трансформаuія.

${ }^{1}$ Тут і далі дати подаються за чинним на час подій стилем.
$\mathrm{Y}$

країнська Центральна Рада - парламент Української Народної Республіки - більшість часу свого існування у 1917-1918 роках працював у Києві у будинку по вулиці Володимирській, 57, який ще довго, за звичкою (неофіційно) називали будинком Центральної Ради.

Історія цього будинку почалася в період революційних подій 1905-1907 років, коли київська громадськість заявила про потребу приміщення для громадських зібрань. Було підготовлено проект (арх. П. Альошин), залучено фінансування (С. Могилевцев), але столипінська реакція поставила під загрозу реалізацію проекту. Щоб врятувати ситуацію, вирішено було використовувати своєрідне «прикриття» - почати спорудження будинку для Педагогічного музею імені царевича Олексія (Романова). Формальна закладка першого каменю відбулася 30 липня 1910 року르, а відкриття закладу - 5 жовтня 1912 року.

Споруда, збудована у стилі модерн на основі російського ампіру, незважаючи на вдале вирішення архітектурного об'єкта як такого, вона не дуже пасувала до київського середовища. Білий колір мало гармоніював $з$ сусідніми спорудами - червоним класичним університетом, охристою Першої гімназією, оперним театром, пансіоном графині Левашової та ін.

Будинок триповерховий плюс цокольний поверх. Планувальним осердям будинку, його найбільшою частиною була зала-аудиторія, $з$ великою скляною банею над залою. Частина приміщень відводився для Педагогічного музею, частина під бібліотеку, окре- 
${ }^{2}$ Центральний Державний архів літератури та мистецтва України. (ЦДАЛМУ) Ф.8, оп. 1, спр. 431, арк. 2-3. мі зали призначалися для виставок та для зібрань. В цокольному поверсі містилися системи обігрівання та вентиляції, допоміжні служби, на тому поверсі була трикімнатна квартира для проживання «завгоспа».

П. Альошин у пояснювальній записці до проекту (1910р.) пише, що «розподіл окремих приміщень взято з розрахунку постійного життя иьього закладу, а тому у цеентрі всього будинку поміщена, як найтиповіша частина його, аудиторія таких розмірів (на 610 осіб), щьоб нею могли користуватися не лише для різноманітних читань з чарівним ліхтарем (проектор. - авт.), але щуоб іï використовували як концертний зал з можливістю ставити на невеликій сиені прості вистави» (тут і далі курсив автора).

Будинок зведений з цегли, зовні обкладений товстими плитами «інкерманського каменю» (мохуватковий вапняк з околиць південнокримського м. Інкермана).

Фасад досить лаконічний, півкругла середня частина підкріплюється півсферою бані, невеликий, досить пропорційний ганок не дисонує з масивом споруди. Привертає увагу багатофігурний фриз на теми освіти на висоті другого поверху чолової стіни. Автори фризу студенти Петербурзької академії мистецтв Л. Дітріх та В. Козлов. Варто зазначити, що П. Альошин перед цим вже співробітничав з Л. Дітрихом, який виконав рельєфний фриз для інтер'єрів будинку, спроектованого і побудованого П. Альошиним протягом 1907-1909 років будинку у Петербурзі для Торгово-промислового товариства А. Чувалдіної і Ф. Бажанова (в оформленні інтер'єрів брав участь також художники М. Рєріх та М. Врубель).

Леопольд Дітріх (1877-1954) народився у Варшаві, дитинство провів на Кубані. Вільним слухачем Академії мистецтв став як стипендіат кубанського міста Катеринодара, у 1912 році отримав звання художника. Виконав (частину у співавторстві з В. Козловим) низку декоративних скульптур, в радянський час працював в соцреалістичному стилі, автор багатьох пам'ятників і портретів сучасників. Похований у Санкт-Петербурзі.

Василь Козлов (1887-1940) походив з селян Саратовської губернії. Вільний слухач Академії мистецтв у Петербурзі (19061912), але звання художника не отримав. Створив низку декоративних скульптур для оформлення споруд. За радянської влади став професором скульптурного факультету Академії мистецтв. Спеціалізувався на образах більшовицьких вождів В. Леніна i Й. Сталіна, автор «еталонних» пам'ятників у Ленінграді та багатьох містах СРСР, а також й іншим радянським діячам. Похований в Петербурзі поруч з Л. Дітріхом.

Первісно фриз проектувався як багатофігурна композиція 3 майже двох сотень «костюмованих» постатей, які ілюстрували розвиток освіти від князівських часів до сьогодення.

За задумом скульпторів фриз мав складатися 3 трьох частин, який відображував три періоди розвитку освіти:

"1. Період зображує перші кроки освіти, законовчителів Кирила і Мефодія, переписування книг до навали татар.

2. Від навали татар до Івана Грозного, коли духовенство головним чином підтримувало освіту на Русі. 
${ }^{3}$ ЦДАЛМУ. Ф.8, оп. 1, спр. 431, арк. 7.

${ }^{4}$ Грушевський М. (1989). Спомини. Київ, № 8,135.

5 (1996). Українська Центральна Рада: Документи і матеріали у двох томах. Т.1. 4 березня 9 грудня 1917 р. К., 1996, 341.

\section{3. Від Івана Грозного до теперішнього часу»³,}

Для виконання такого складного завдання необхідно було опрацювати велику кількість історичного матеріалу, але брак часу змусив відмовитися від костюмованих сцен. Постатям і сценам надали універсального «античного» виду, таку собі травесті-версію з елементами сучасності, як-то глобус, книги, приладдя тощо. Коли костюмовані сцени легко можна було «прочитати», то античну версію значно важче. Тепер тільки можна гадати про зміст сцен та хто є хто, впізнати можна, заледве, Аполлона, Меркурія, Афіну...

Робота виконувалася поспіхом, що помітно при ближчому огляді, окремі постаті, особливо в складних ракурсах, явно не вдалися скульпторам. Помітно, що в місцях примикання постатей до архітектурних елементів було грубо обрізано частини тіл.

Скульптори жили і працювали в Петербурзі, ескізи затверджувалися П. Альошиним по фотографіях. Там же в Петербурзі гіпсові моделі переводили у камінь. Стислі терміни примушували погоджуватись 3 недосконалістю виконання. Поспіх також відчувається у виконанні каменярами замовлення, обробка і моделювання постатей спрощені, дещо грубуваті. Рельєфи з Петербурга до Києва привозилися залізницею невеликими партіями (по готовності), де їх одразу і монтували на стіні будинку.

Над рельєфним фризом, по центру, встановили кількаметровий бляшаний російський імперський герб, під ним напис з накладних металевих літер: «На Благое Просвещение Русскаго народа». А нижче, на ганку - «Педагогический Музей Цесаревича Алексея».

Над двома бічними входами маскарони, один мав явні риси філософа Сократа (на основі традиційного античного зображенням), а інший до нашого часу дійшов пошкоджений, так, що важко зрозуміти, хто був первісно зображений.

$* * *$

Перші зміни будинку, власне, екстер'єру відносяться до часу, коли тут працювала Українська Центральна Рада.

Первісно Рада займала одну кімнату та, за словами голови Генерального Секретаріату В. Винниченка, ще два «закапелочки». Сталося це у перших числах березня 1917 року.

Голова УЦР М. Грушевський який приїхав до Києва в середині березня, коли Рада вже працювала у будинку Педагогічного музею, писав: «Центральна Рада для своӥх зібрань дістала від міської Думи в Педагогічному музеї нібито дві кімнати, а властиво одну, котра була потім моїм кабінетом, коли Ц[ентральна] Рада заволоділа всім будинком, а друга - се був темний коридорчик, куди виходили двері з усіх кімнат.».

Рішенням Генерального Секретаріату від 11 жовтня 1917 року на пропозицію генерального секретаря освіти І. Стешенка ухвалено: «прийняти утримання будинку Педагогічного Музею на кошmи Генерального Секретаріату» ${ }^{5}$ і 3 того часу Центральна Рада стала повноправним «господарем» будинку Педагогічного музею.

Перші зміни зовнішнього опорядження будинку Центральної Ради розпочато в середині березня 1918 року, коли вирішено зня- 
${ }^{6}$ (1996). Українська Центральна Рада: Документи і матеріали у двох томах. Т.1. 4 березня 9 грудня 1917 р. К., 1996, C. 343 .

7 Там само, 42

\footnotetext{
8 Українська Центральна Рада: Документи і матеріали у двох томах (1997). Т.2. 10 грудня 1917p. - 29 квітня 1918p. K, C, 236.

9 Українська Центральна Рада: Документи і матеріали у двох томах (1996). Т.1. 4 березня 9 грудня 1917 р. К., 1996, C. 120 .
}

ти царського орла та ліквідувати написи, як невідповідні новому статусові будинку.

19 березня (в день перепоховання героїв Крут) герб демонтували, при тому звук від удару об землю був такий, що присутні у залі засідання вирішили, що то вибух ${ }^{6}$.

У той же день УЦР ухвалила «почепити прапор на будинкові, в якому збирається Ц[ентральна] $Р[a \partial a]{ }^{7}$, що і було зроблено. Найближчими днями, ліквідувавши на фасаді старі написи, на чоловій стіні встановили герб УНР - Тризуб.

Тризуб та синьо-жовтий прапор протримався до приходу більшовиків, які їх зняли. Натомість фотографії 1920-1930-х років фіксують на місці тризуба (перед тим орла) п’ятикутну зірку, так само встановлено було зірку на верхівці флагштоку на бані. 3 часом червона зірка з стіни зникла і вона залишалася без «прикрас».

Традицію вивішувати над будинком синьо-жовтий прапор відновили лише в часи незалежності.

\section{Інтер'єр.}

В середині будинок - коридори, сходи, кімнати, був прикрашений ліпниною. До того ж ліпнина була частково поліхромною, що вносило непотрібну строкатість і не зовсім гармоніювало 3 досить строгим екстер'єром. Сучасного вигляду інтер'єри набрали 1937 року та 1945 року, внаслідок ремонтів та перебудов, коли значну частину ліпнини було знято та ліквідовано поліхромність, що пішло лише на користь.

Зала первісно була прикрашена скульптурними (рельєфними) зображеннями. Над сценою по центру в колі містився профільний барельєфний портрет малолітнього Олексія Романова, який, підтримували, витягнувшись поземно елегійні «німфи». Сцену по боках прикрашали парні пілястри, над якими вгорі розташовані однакові імперські герби, над ними цифри - 1861 i 1911, тобто дата скасування кріпацтва та його п’ятдесятилітній ювілей.

За задумом архітектора П. Альошина три, не рівних за площею плафони над сценою зали мали прикрасити живописні панно на теми освіти. Архітектор домовлявся з О. Мурашком та російським митцем Б. Кустодієвим. Уявлення про задум розписів можна скласти лише на основі друкарського відбитка (не найкращої якості) кресленика розрізу будинку, де видно, що плафони заповнені багатофігурними розписами, це конкретні композиції, а не просто проектне фонове заповнення. У такому вигляді, без розписів та 3 рельєфами, зала простояла до кінця березня 1917 року, коли Центральна Рада провела незначний ремонт зали та внесла корективи у декор. Роботи тривали з 30 березня до 12 квітня, а засідання УЦР проходили «в одній з малих зал Центральної Ради»» .

23 червня 1917 р. делегати Першого Всеукраїнського селянський з’їду, що проходив у Києві, прийшли привітати Центральну Раду як вищий орган влади, і подарували «Центральній Paдi nортрет T. Шевченка, випалений на дереві» ${ }^{9}$, і тут же було запропоновано зняти барельєф цесаревича, а натомість помістити на стіну подарований портрет Кобзаря. Як довго ще провисів барельєф цесаревича, точно встановити не вдалося, але сталося це 
${ }^{10}$ ЦДАЛМУ, Ф.8, оп. 1, спр.57, арк. 47.

\footnotetext{
${ }^{11}$ Хаустов, П. (1937). Музей В.І. Леніна в Києві. Сойіалістичний Київ, № 3, C. 9 .
}

влітку того ж року - разом з портретом було демонтовано імперську символіку.

4 серпня 1917 р. Тимчасовий уряд Росії змушений був визнати українську юрисдикцію над Київською, Полтавською, Подільською, Волинською і Чернігівської (без Стародубщини) губерніями. Одразу після цього зал засідань Центральної Ради оздобили гербами цих губерній.

Нова комуністична влада, приводячи до «свого» ладу споруду 1923 р. вирішила ліквідувати герби, як пережиток «контрреволюційної Ради». Архітектор П. Альошин у листопаді 1923 року оскаржував це рішення, він звернувся до фахівців, а саме професора Всеукраїнського інституту пластичних мистецтв Ф. Ернста та професора Київського архітектурного інституту I. Моргилевського, які визнали, що ліквідація гербів «лишило композицію плафону художньої єдності і геть знецінило його як архітектурно-художній твір» ${ }^{10}$, але вже було запізно.

$* * *$

В наступні роки в приміщенні по вул. Володимирській, 57 містилася низка установ, зокрема Інститут міжнародних відносин (19201921), Пролетарський музей та київський губерніальний Істпарт (комісія з вивчення історії жовтневої революції та комуністичної партії) (1921-1924), Музей Революції (1924-1934), Київський обласний виконавчий комітет Київської обласної ради (1934-1937) тщо.

1937 року після відкриття Музею Леніна у Москві (1936 р.) гарячково почали готувати аналогічні музеї у республіках. Вирішено, що у Києві «за ухвалою партї та уряду також буде створено музей В. I. Леніна як філію московського музею» ${ }^{11}$. Для влаштування київської філії обрали колишній будинок Центральної Ради. Облвиконком, що тоді займав приміщення, терміново перенесли до будинку нинішнього Музею Тараса Шевченка на бульварі Т. Шевченка, 12.

Для проекту Музею Леніна існуюче приміщення було замалим, вирішено його добудувати і реконструювати. Внаслідок непрозорих та кулуарних домовленостей, проект добудови та розширення споруди підготовлений начальником 2-ї архітектурної майстерні Київради архітектором О. Лінецьким (він 1935 р. заступив П. Альошина на цій посаді) був відхилений, а несподівано затверджено проект архітектора П. Альошина (на той час безробітного), йому ж доручили нагляд за будівництвом. Будівельні роботи закріпили за «найвідповідальнішою» установою радянського часу Народним комісаріатові внутрішніх справ УРСР (НКВС УРСР), власне, управлінню особливого будівництва, що спеціалізувалося на зведенні в'язниць та концтаборів, урядових будинків та дач для номенклатури. При вказаному управлінні було створено окрему «Будівельну дільницю Музею В. І. Леніна». 11 квітня 1937 року НКВС підписала з П. Альошиним угоду на виконання проекту, робочих креслень та ведення нагляду за будівельними та оздоблювальними роботами. 
${ }^{12}$ Хаустов, П. (1937). Музей В.І. Леніна в Києві. Сочіалістичний Київ, № 3, C. 11.

${ }^{13}$ Пам'ятник демонтований в час Революції Гідності у грудні 2013 року.
Архітектор, зберігаючи єдність стилю, поширив бічні сторони вглиб ділянки та замкнув їх блоком, паралельним чоловій частині, чим було утворено невеликий двір де ним «в дусі аналогічних італійських дворів і прикрашується партерною зеленню, квітами, скульптурами і фонтаном» ${ }^{12}$. Певних змін зазнало внутрішне оздоблення (у бік спрощення) та планування окремих приміщень. Цікаво, що барельєфний фриз екстер'єру продовжений не був.

В існуючому конференц-залі музею, де у 1917-1918 роках засідала Центральна Рада, обабіч сцени встановлено дві гіпсові скульптури - Леніна і Сталіна, роботи російського радянського скульптора С. Меркурова. Гранітні «оригінали» 1939 року експонувалися в США на всесвітній виставці. 1946 року Скульптуру Леніна встановили на початку бульвару Т. Шевченка навпроти Бессарабського ринку ${ }^{13}$.

Цікаво, що при добудові та ремонті 1937 року П. Альошин знову повернувся до задуму заповнити зал розписами. Цього разу, з огляду, на те, що будинок готувався під музей В. Леніна, тематика розписів мала бути відповідною. Одразу зазначимо, що розписи не було виконано, вірогідно головною перешкодою був брак часу.

Проте до питання розписів повернулися після війни, коли знову запрацював Музей В. Леніна. Цього разу, а це був 1951 рік, проект розписів підготував недавній випускник (1947р.) Київського художнього інституту Б. Піаніда. Теоретична частина підготовки розписів лягла в основу його дисертації «Монументальний живопис у конференц-залі музею В. І. Леніна в Києві», яку він вдало захистив. У той же час з розписами у Б. Піаніди не склалося, так що зал залишися без них. На тому місці над сценою, де колись був барельєф царського сина, а потім Т. Шевченка помістили барельєфи комуністичних вождів в обрамлені прапорів.

Декоративні прикраси в інтер'єрі, ліпнину на стінах і стелі, що довший час була поліхромною, «спростили», прибравши частину, решту пофарбували у колір стін. Одночасно оновили прилади електроосвітлення, меблі тощо.

У такому стані споруда дійшла до часів незалежності України. Про Будинок учителя почали говорити, як про колишній будинок Української Центральної Ради. 1995 року на чоловій стіні встановлено анотаційну таблицю з текстом: «У цьому будинку з 4/17 березня 1917 р. по 29 квітня 1918 р. діяла Українська Центральна Рада - перший представницький орган незалежної України», а у фойє - меморіальну таблицю із зображенням провідних діячів УНР (автори В. Сівко і М. Білик).

1998 року до сьомої річниці Всеукраїнського референдуму на підтвердження Акту про державну незалежність України поруч з будинком Центральної Ради зведено пам'ятник Голові УЦР М. Грушевському (скульптор В. Чепелик).

Під час відзначень 125-ліття від дня народження Голови Директорії УНР С. Петлюри на чоловій стіні будинку урочисто відкрито анотаційну таблицю про те, що на виконання Указу Президента України тут буде споруджено пам'ятник С. Петлюрі. Проект пам'ятника розробила творча група на чолі із скульптором В. Луцаком. 
В одному із залів 2009 р. відкрито «Музей Української революції 1917-1921 років», який висвітлює перебіг державотворчого періоду, готується музеєфікація кабінетів голови Центральної Ради М. Грушевського та голови Генерального секретаріату В. Винниченка що примикають до експозиційного залу Музею.

Як бачимо, зміни і трансформації досить нетрадиційного для київської архітектури будинку по вулиці Володимирській, 57 у більшості ситуацій контролювалися архітектором П. Альошиним, який зберіг стильові особливості архітектури початку XX століття, а привнесене усе ж не порушувало загального враження.

\section{References}

Haustov. P. (1937). Muzeiy V.I. Lenina v Kyievi. Sochialistichniy Kyiv. № 3

Hrushevskyi M. (1989). Spomyny. Kyiv, №8

Ukrainska Centralna Rada. Dokumenty i materialy u dvoh tomah. (19961997). Kyiv.

\section{Kucheruk Oleksandr}

\section{THE HOUSE OF THE CENTRAL COUNCIL IN KYIV: TRANSFORMATIONS OF THE IMAGE}

The article deals with the history of construction and functioning of the building at Volodymyrska St., 57 in Kyiv. During the Ukrainian Revolution, it was used as the location of the Central Council of Ukraine. The concept of building of this house is analyzed, the description of interior and exterior decoration is presented. The process of transition of the building to the status of the residence of the Central Council of Ukraine is described in detail. The further fate of the Central Council House, the functional transformation that it faced in the various periods of existence was investigated.

Key words: building of the Central Council of Ukraine, construction, transformation, first half of $20^{\text {th }}$ century. 